\title{
Determination of the transfer step of the ore chute while mining the technogenic deposit of the bulk type
}

\author{
Volodymyr Peregudov ${ }^{1}$, Ihor Hryhoriev ${ }^{1}$, Serhii Joukov², and Yulian Hryhorieve, ${ }^{2, *}$ \\ ${ }^{1}$ SDI "Krivbassproekt", 40 Poshtoviy Ave., Kriviy Rih, 50000, Ukraine \\ ${ }^{2}$ Kryvyi Rih National University, Mining and Metallurgical Faculty, 11 Vitalii Matusevych Str., Kryvyi Rih, 50027, Ukraine
}

\begin{abstract}
Further development of the open mining works on the domestic enterprises will be accompanied by the worsening of mining-geological conditions and declining of the quality of iron ore raw materials. In the same time, the accumulated mining wastes, that can make the technogenic deposits, pass into one of the important sources of the mineral raw materials. Taking into account this thing, the development and implementation of the modern technological circuits of the technogenic deposit development is an actual calling for mining industry, and determination and optimization of process conditions of the technogenic deposit development - is the scientific task of this publication. The obtained results of studies of the optimum step value of the ore chute transfer during the technogenic deposit development can be used by design organizations and mining enterprises for designing works. The obtained methodology and the proposed mathematical dependencies will reduce the cost of mining of the technogenic deposit due to the reasonable timely transfer of the open ore chute.
\end{abstract}

\section{Introduction}

As a result of activities of the mining and processing industry of the Kryvyi Rih region, hundreds of millions of cubic meters of production waste are accumulated on the surface in the form of overburden, sludge, slag, ash and so on, that increase the environmental load. More than 2 billion tons of rock mass is extracted annually from the Ukrainian subsoil, $60-70 \%$ of which is stored in the dumps. However, the level of utilization of production waste reaches only $12-15 \%$, while in the advanced countries of the world it reaches $80 \%$. The tendency for the use of secondary resources is observed in the USA, Japan, Canada, Great Britain, France, Germany, Republic of South Africa and other industrialized countries [1-4].

According to various estimates, up to 13 billion tons of overburden and up to 6 billion tons of washery refuses of low-grade iron ores are contained in the dumps and tailings ponds of Kryvyi Rih mining and processing enterprises. At the same time annual economic damage from environmental pollution is estimated at $\$ 300$ million. However, the prospects for the development of mining are characterized by an increase of the mineral output with a constant decrease in their quality and complication of the conditions of exploitation of natural deposits. In future, deposits of low quality ores, comparable to the ores of technogenic deposits, will be involved in the development.

The amount of mineral resources contained in mining waste is anthropogenic raw material, the involvement of which in the processing will reduce the cost of exploration for new and mining of exploited deposits, release land occupied waste and their reclamation, elimination of sources of pollution from the surrounding environment around operating enterprises [5].

Thus, anthropogenic formations formed by the storage of mining and processing waste, provided the required quantity and quality of mineral raw materials, can be suitable for industrial use and as a result can be considered as technogenic deposits.

By definition of V. O. Gneushev [6], man-made mineral deposits are places of accumulation of mineral extraction and processing of mineral resources whose reserves are estimated and have industrial significance. Like natural mineral deposits, such deposits have a certain structure spreading of useful components, the zone of secondary enrichment and oxidation.

It is established that the deposits that are mined in $40^{\text {th }}-50^{\text {th }}$ of 20 century, accumulated a significant amount of technogenic waste with relatively high content of useful components, because at that time the extraction and processing conditions were much higher than today [7].

Dumps of Kryviy Rih mining enterprises are made up of overburden rocks that have been removed from the subsoil, moved and stacked. Their mineral and chemical composition, texture, structure, physical, technological, technical and other characteristics have practically not changed in comparison with the corresponding parameters of these rocks in the geogenic deposit.

Thus, the accumulated mining waste, which may be technogenic deposits, will eventually become one of the important sources of mineral resources. In view of this,

\footnotetext{
* Corresponding author: Juliangrig@gmail.com
} 
the problem of development and improvement of formation and mining technologies of technogenic deposit with optimal parameters that would ensure maximum efficiency of its development is especially upto-date and needs further research.

\section{Materials and methods}

V. D. Evtekhov [8] claims that the technogenic deposits represented by the waste heaps of mining enterprises have been studied more deeply to date, and the first steps have been taken in the direction of their industrial exploitation. For some rocks extracted from the depths along with iron ores, and for some areas of their application, the problem of recycling can be considered theoretically and practically solved.

For example, the production of rubble stone, ballast raw materials, as well as materials for road construction of granitoids, substandard magnetite-silicate quartzites and different composition of shale.

Undoubtedly, the development of bulk man-made deposits would be economically feasible. This is due to the fact that the cost of finished products from manmade raw materials is lower than the primary cost of raw materials extracted from the subsoil.

In addition, the terms of development of technogenic deposits from exploration to production of the finished product is much less than in geogenic one.

In order to bring the technogenic deposit into operation, it is necessary to solve a complex problem, which includes a number of issues, such as determining the mineralogical composition of the technogenic deposit, its area and capacity, the content of the useful component, the particle size spreading; identifying the most promising areas; collecting data on the spatial spreading of pollution in man-made sediments; estimated calculation of inventories of useful components, as well as a plan of development taking into account technological types of shifts and compilation of geological map and sections [9]. However, the haphazard storage of rocks in the dumps leads to complications in their development as man-made deposits, which is explained by the higher costs of performing the required amount of mining work on the extraction of mineral resources.

V. V. Kustov proposes [10] to use the phenomenon of segregation, which is the process of separation of bulk material by size as a result of interaction between particles of bulk material and additional external factors, to predict the parameters and qualitative assessment of the massif of rocks of technogenic deposits. The author notes that the effect of segregation is occurs in the dumping of waste rocks, and therefore it is important to know the regularities of segregation processes in determining technological schemes of repeated impact on the dumps, in solving problems of engaging in the production of technogenic deposits with certain zones of concentration of useful component of the bulk and prediction of objects. Therefore, according to the author, one of the main criteria when choosing a rational technology for the formation of anthropogenic deposit is the degree of segregation of bulk rock, which will allow to form an technogenic deposit with the necessary parameters that would provide a given quality of mineral raw materials.

On this basis, Kustov developed 11 technological schemes for the use of dump equipment for the formation of technogenic deposits of layered structure, which would provide the maximum degree of segregation of bulk rocks with the purpose of maximum material disclosure in size.

The developed technological schemes involve the use of conveyor or wheel transport and are distinguished by the technological operations performed. The most effective technological schemes in terms of qualitative separation of loose rocks into fractions are schemes with conveyor dumping and in the case of dump trucks for peripheral dumping.

The group of scientists of IGTM NAS of Ukraine under the leadership of M. S. Chetverik productively explored the problem of the technology of technogenic deposits' development [11], but mainly deposition of shore type, that significantly narrows the scope of the results.

A team of scientists from Kazakhstan led by Ye. I. Rogov investigates the development of technogenic deposits of bulk type, but with the use of leaching [12]. However, this technology cannot be effectively applied for the Kryvyi Rih iron-ore deposits. In addition, its application will increase the environmental load to the region.

Well known the schemes of selective storage of rocks in waste dumps: storage of each separate type of raw material on its own, separated in parts of surface area; storing different types of raw materials in one plot with their distribution in plan; storage of different types of raw materials in one section with their height distribution; storage by a combination of the second and third methods. Storage by the first method is in fact a common dumping. Selective storage with height distribution of raw materials is possible when the prospective value of the ores is clearly defined. At the same time, the least valuable ores should be at the base of the rock mass and deep into its side parts, and the most valuable ones should be at the upper tiers of the technogenic deposit. The most valuable fraction will be concentrating on the outer sides of the rock mass, so its subsequent shipment will not cause any inconvenience. However, over time, the importance of certain types of minerals may change, so the current storage system in the future may interfere with access to the mineral component.

In this way, the most selective warehousing technologies provide for the opening of a deposit only after its backfilling by passing the surface trenches [1315]. Technology for the formation of technogenic deposits with the establishment of tunnels system and ore pass, described in the investigation [16] has fundamentally difference from the described ones.

This technology involves the discovery of a bulk technogenic deposit as an object of development, still in the formation stage. The developed technology allows to reduce the costs for development of the technogenic 
deposit and to increase the completeness of the mineral's extraction by simplifying the access of extractive equipment to the mineral. Despite this, this technology has several disadvantages:

- the formation and processing of technogenic deposits in this way involves significant capital expenditures during the building phase. At the same time, $17 \%$ of them are the cost of laying the fastening system, which is explained by the complexity of the installation work and the high cost of the used materials;

- fastening system that is in the thickness of the technogenic field, especially horizontal tunnels, require periodic metrological control, because they are in a constantly tense state;

- the installation of the vertical fastening system requires only a bulldozer peripheral method of dumping. It is characterized by an almost uniform distribution of oversize over the thickness of the technogenic deposit;

- in this technological scheme with the placement of vibratory feeders at the bottom of the vertical cavities, is possible emergency stop of work due to oversize of rock. Therefore, the proposed technological scheme requires a uniform particle size distribution without oversize.

The technology of the technogenic deposit development with open ore chutes is free of the above mentioned disadvantages. In this case the formation of the technogenic deposit is performed by known storage technologies, and after the backfilling of the technogenic deposit or if a certain slope enters on the designed contour, a mobile or stationary ore chute in the form of an open trench can be formed on it. A transfer bin equipped with a vibrating feeder is placed at the bottom of the ore chute. The method of the technogenic deposit development is as follows: the wheel loader removes the minerals from the face and transports it to the accumulating tank, from where it is delivered over the open ore chute to the vibrating feeder under the action of gravitational forces and transferred to the means of railway transport. Choosing the location of the technological complex we should take into account the effective distance of transportation of the wheel loader, that is limited to $500 \mathrm{~m}$. However, this publication does not consider the choice of the direction of development of mining works from the receiving tank of the vibrating feeder, the optimal values of the width of the work stope and other parameters of the elements of the development system.

At the same time, the development of the technogenic deposits of the bulk type according to this technology is an imperfect and is characterized by low technical, economic and technological indicators, which keep its further introduction. This situation can be corrected by identifying and optimizing the parameters of the elements of the technogenic deposit development system, as well as further improving existing technologies by increasing the efficiency of equipment use.

\section{Results and discussion}

For a detailed study and further research of the technological scheme was first investigated range of pneumatic wheel loaders. It was considered five pneumatic wheel loaders on the example of the model range of the "Caterpillar" company. First of all, the technical parameters of the CAT-962L, CAT-966L, CAT-980H, CAT-992K, CAT-993K machines were analyzed [17], and then their productivities were calculated for the conditions of technogenic deposits.

For these conditions capital and operating expense for mining of technogenic deposit with each loader were calculated. For the accuracy of the results, calculations were made for transport distances of $100 \mathrm{~m}, 200 \mathrm{~m}, 300$ $\mathrm{m}, 400 \mathrm{~m}$ and $500 \mathrm{~m}$. The results of these calculations of capital and operating expense per $1 \mathrm{~m}^{3}$ of the rock are shown in table 1 .

Table 1. Calculation of total CAPEX and OPEX for the different pneumatic wheel loader, USD per $1 \mathrm{~m}^{3}$

\begin{tabular}{|c|c|c|c|c|c|}
\hline $\mathbf{L , M} E, \mathbf{m}^{3}$ & 4,4 & 7,4 & 8,2 & 12,3 & 23,7 \\
\hline 100 & 0,07 & 0,05 & 0,06 & 0,25 & 0,21 \\
\hline 200 & 0,11 & 0,09 & 0,11 & 0,48 & 0,34 \\
\hline 300 & 0,11 & 0,09 & 0,11 & 0,48 & 0,34 \\
\hline 400 & 0.23 & 0.17 & 0.21 & 0.86 & 0.71 \\
\hline 500 & 0,29 & 0,21 & 0,28 & 1,15 & 0,86 \\
\hline
\end{tabular}

Consideration of the proposed examples of equipment from the point of view of economic feasibility, performance or combination of these components will indicate the absolute inappropriateness of the application of the CAT-992K brand with a bucket volume of $12,3 \mathrm{~m}^{3}$, since this sample cannot compete with any of the presented models, having high specific indicators costs at relatively low productivity.

The results obtained allow us to conclude on the economic feasibility of using pneumatic wheel loaders CAT-962L, CAT-966L, CAT-980H for mining of technogenic deposits with open ore chute. The results are shown in fig. 1.

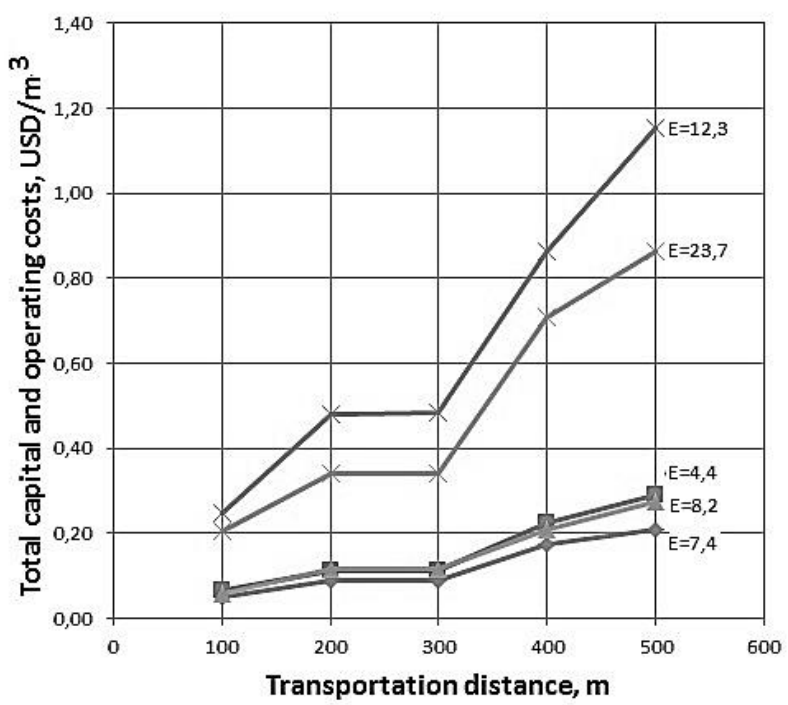

Fig. 1. Dynamics of mining costs for loaders with different buckets $(E)$ depending on the distance of transportation.

But for the further research we will select loader 
CAT-966L, which has the best technical and economic indicators.

Obviously, in order to maximize the productivity of the loader, which operates according to the technological scheme with open ore chute, the distance of transportation of technogenic raw materials should be minimal. Such condition will be fulfilled, developing the massif by radial slicing, as shown in fig. 2. The essence of technology is as follows.

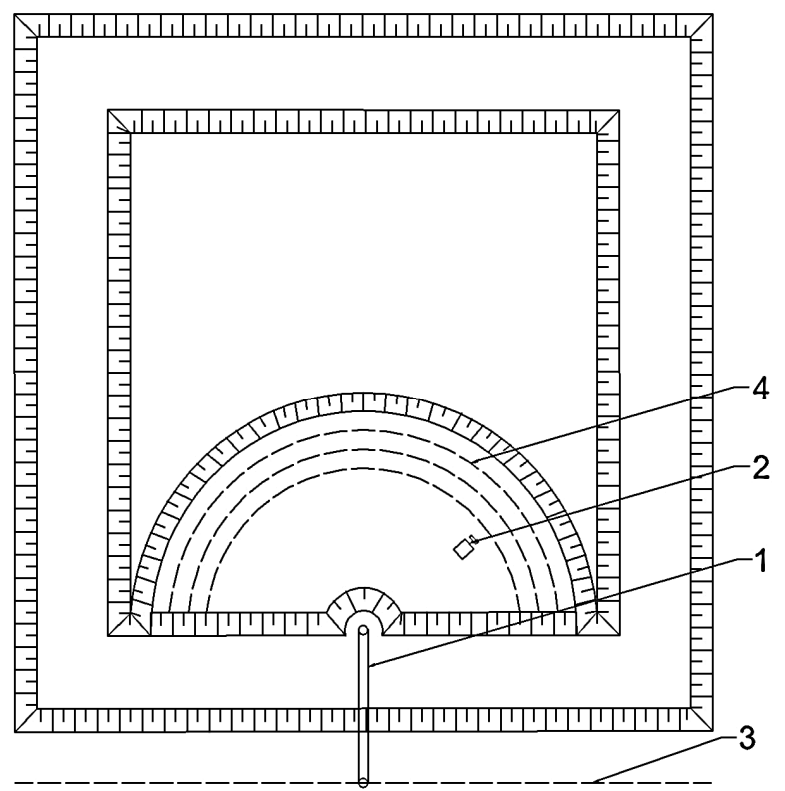

Fig. 2. Scheme of development of the technogenic deposit by radial slicing with pneumatic wheel loader: 1 - open ore chute; 2 - pneumatic wheel loader; 3 - axis of a railway transport; 4 radial slicing.

The loader begins to develop the deposit directly near the ore chute at the shortest transport distance, thus forming a radial slicing. After that, it comes to the next slice with a larger radius and so on. The extension of the radius continues until the transport length reaches the limit, which is usually assumed $500 \mathrm{~m}$ for wheel loaders. The aim of the proposed technology is in the constant minimization of the transportation distance of the mining mass from the face to the receiving tank of the open ore chute. So, we transfer the development of the mineral, which is to be transported to a larger distance, to the later period. As a result, discounted costs for the transportation also diminish.

Let's make a model of mining works on the technogenic deposit. The following mathematics calculation will be done for these purposes. The volume of the first slice will be calculated from the elementary formula of a half of an area of a circle $V=0,5 \pi L^{2} h_{s}$.

Now we will calculate the volume of every following slice according to the formula (1):

$$
V=\frac{\pi\left(L^{2}-l^{2}\right) h_{s}}{2},
$$

where $L$ - radius of a current radial slice, $\mathrm{m}$

$l$ - radius of a previous radial slice, $\mathrm{m}$

$h_{s}$ - high level of a stage of the technogenic deposit, $\mathrm{m}$

At the same time the volume of a slice is equal to the product of the loader's productivity to the time of the development. On the base of preliminary calculations, we can determine the time of the slice development according to the formula (2):

$$
t=\frac{\pi h_{S}\left(L^{2}-l^{2}\right)}{2 Q_{p n}},
$$

where $Q_{p n}$ - productivity of a wheel loader, $\mathrm{m}^{3} / \mathrm{t}$.

For the conditions of using the pneumatic wheel loader CAT-966L with the height of a stage $12 \mathrm{~m}$ we will make calculations for different transportation distances from 10 to $500 \mathrm{~m}$ with the step $10 \mathrm{~m}$ and tabulate the results in table 2 .

Table 2. Calculation of working time of radial slicing for the pneumatic wheel loader

\begin{tabular}{|c|c|c|c|c|}
\hline $\mathbf{L}, \mathbf{m}$ & $\mathbf{Q}_{\mathbf{p n}}, \mathbf{~ m}^{\mathbf{3}} / \mathbf{s h}$ & $\begin{array}{c}\text { Cumulative } \\
\text { working time, } \\
\text { sh }\end{array}$ & $\begin{array}{c}\text { Time of } \\
\text { radial slicing } \\
\text { working, } \mathbf{~ s h}\end{array}$ & $\begin{array}{c}\text { Volume of } \\
\text { radial } \\
\text { slicing, } \mathbf{~ m}^{\mathbf{3}}\end{array}$ \\
\hline $\mathbf{1 0}$ & 20753,1 & 0,1 & 0,1 & 1885,0 \\
\hline $\mathbf{2 0}$ & 18078,5 & 0,4 & 0,3 & 5654,9 \\
\hline $\mathbf{3 0}$ & 16014,6 & 1,0 & 0,6 & 9424,8 \\
\hline $\mathbf{4 0}$ & 14373,6 & 1,9 & 0,9 & 13194,7 \\
\hline $\mathbf{5 0}$ & 13037,7 & 3,2 & 1,3 & 16964,6 \\
\hline$\ldots$ & $\ldots$ & $\ldots$ & $\ldots$ & $\ldots$ \\
\hline $\mathbf{4 7 0}$ & 2658,8 & 1115,8 & 65,9 & 175300,9 \\
\hline $\mathbf{4 8 0}$ & 2609,3 & 1184,4 & 68,6 & 179070,8 \\
\hline $\mathbf{4 9 0}$ & 2561,7 & 1255,8 & 71,4 & 182840,7 \\
\hline $\mathbf{5 0 0}$ & 2515,7 & 1330,0 & 74,2 & 186610,6 \\
\hline
\end{tabular}

On the basis of the received data, we can make a diagram of dependence of the transportation distance on the time, which was taken for the development of the radial slicing (Fig. 3).

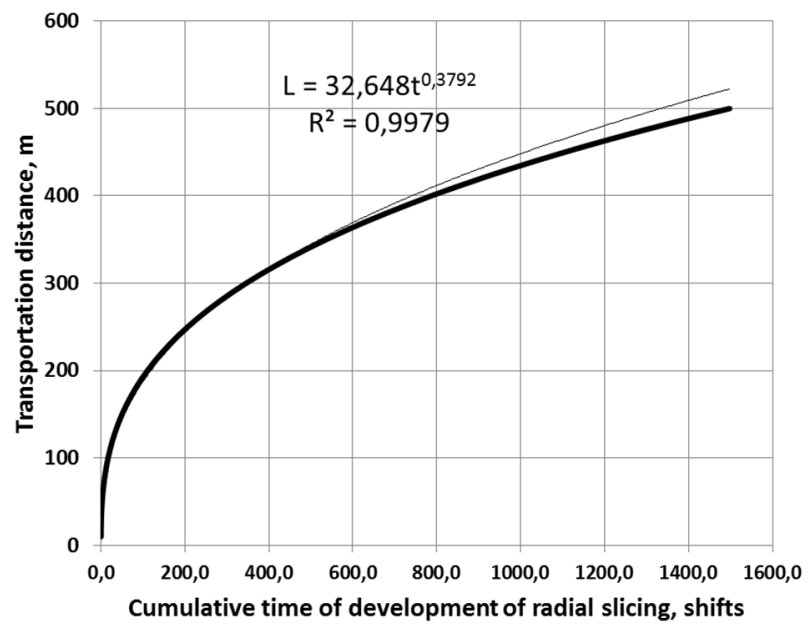

Fig. 3. The dependence of the transportation distance by the radial slicing on the time of the development.

This dependence can be described by the equation of the exponential function $L=32,648 t^{0,3792}$. The obtained diagram allows approximately determine the rate of movement of mining works at the technogenic deposit and dynamically plan mining works on different stages.

On the one side, the proposed technology of development by radial slicing transfer transportation expenses to the later period, but afterwards it will require additional units of mining and transport equipment. 
Calculations, performed in the previous sections, allowed to make a conclusion that the productivity of the loader will reduce while removing the face from the ore chute. This clearly shows the diagram of the loader productivity on the radius of the radial slicing (fig. 4).

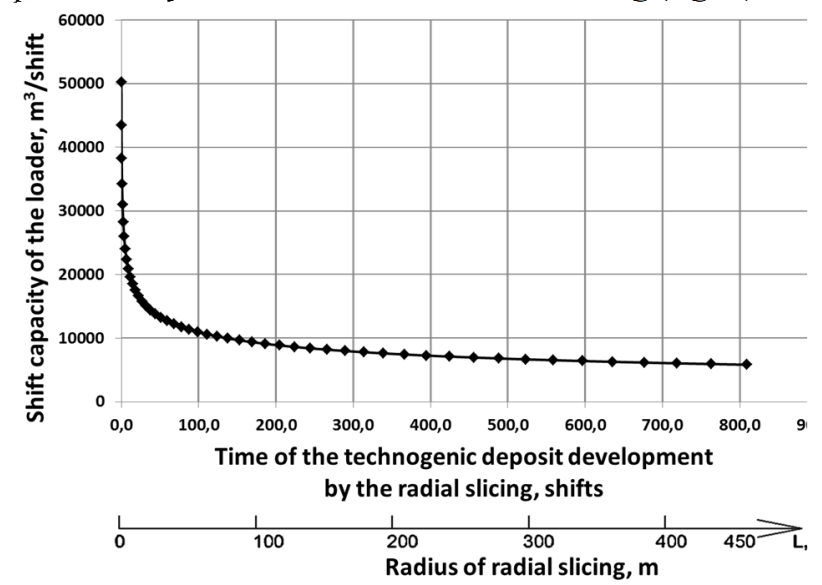

Fig. 4. The dependence of the shift capacity of the loader on the working time with increasing radial slicing radius.

As a result of the conducted researches there was an idea to reduce transportation distance by transferring the open ore chute. It will provide the rise in productivity and, consequently, will diminish the equipment stock and the development period of the technogenic deposit. During the periods of increasing transportation distance, the transfer of the ore chutes will allow to keep the equipment stock at a constant level.

However, there is a question of the step of its reinstalling. On the one side, an insufficient transfer step will result in a higher cost of dismantling and installation of the ore chute and the vibrating feeder. On the other side, the work with a long transportation distances increases operating costs.

So, the rational value of the transfer step should be determined by the economic criteria.

We describe mathematically the necessary condition of equality by the formula (3).

$$
C \times t+E K=C \times(t-\Delta t)+E K+\Delta C
$$

where $C$ - specific operating costs for the loaders, ore chutes and feeders, USD/shift;

$\Delta C$ - additional operating costs for dismantling/installation of vibrating feeders and ore chutes, USD;

$K$ - capital expenditures for loaders, ore chutes and feeders, USD;

$t$ - time of working of the radial slicing according to the basic variant, shifts;

$\Delta t$ - change (reduction) of working time due to the transfer of ore chutes, shifts;

$E-$ norm. coefficient of reduction of capital expenditures.

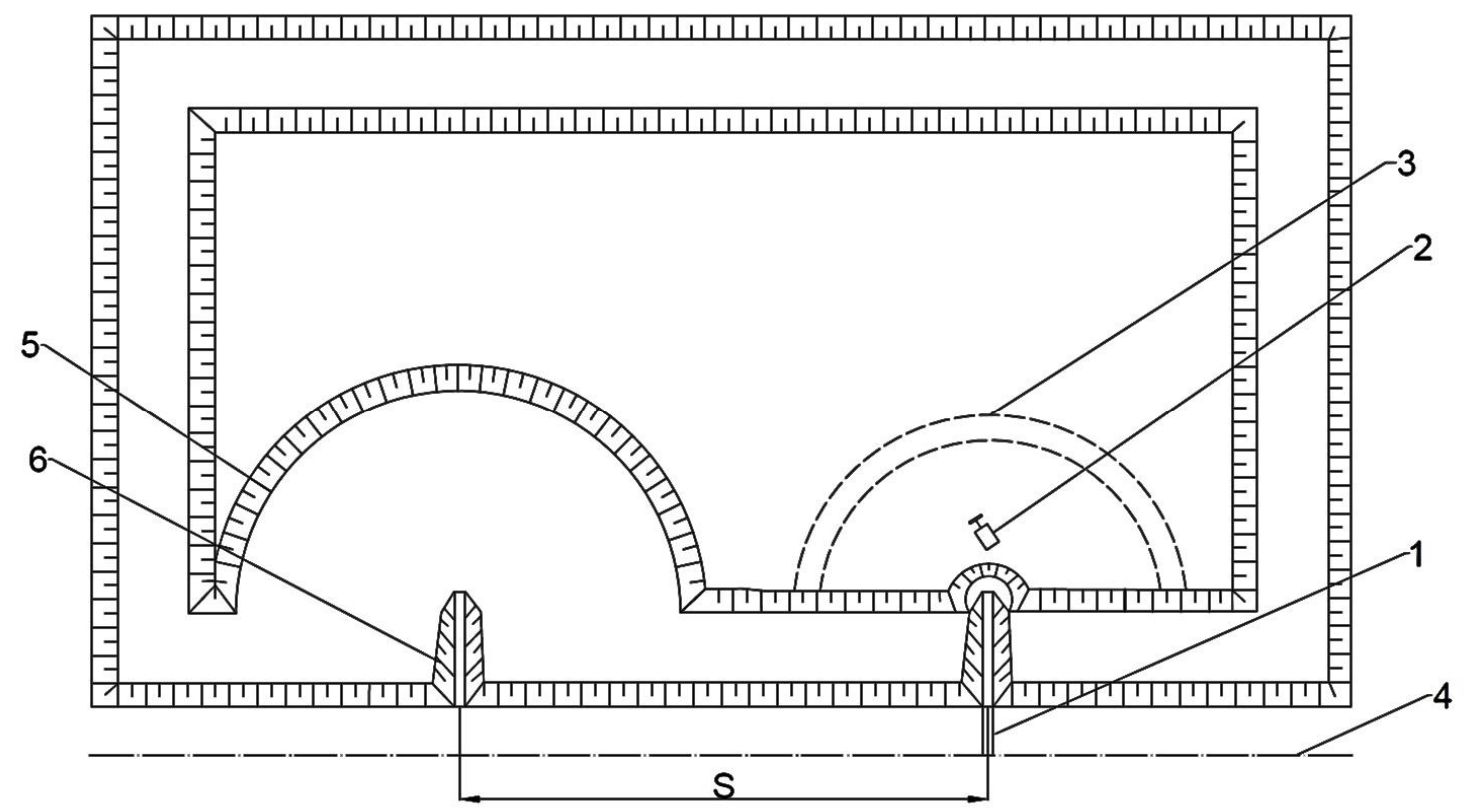

Fig. 5. Scheme of development of the technogenic deposit with reinstalling of the open ore chute: 1 - open ore chute in new in the current position; 2 - pneumatic wheel loader; 3 - radial slicing; 4 - axis of a railway transport; 5 - radial slicing for old open ore chute position; 6 - open ore chute in the old position; $S$-step of reinstalling of the open ore chute.

Let's simplify the expression, change the working time with respect to the volume change to productivity, which in turn also depends on the transportation distance and time, take into account the system of restrictions and obtain a mathematical model for the technogenic deposit in 2 stages and get formula (4):

$$
\begin{gathered}
\sum \mathrm{C} \frac{\pi\left(L_{i}^{2}-L_{i-1}^{2}\right) h_{s}}{2 Q(t)_{i}}-\Delta \mathrm{C} \rightarrow \min \\
\left\{\begin{array}{l}
L_{\mathrm{i}} \geq L_{i-1} \\
h_{s}=[8 ; 15],
\end{array}\right.
\end{gathered}
$$


where $i$ - optimization is completed according to the number of radial slicing, every increasing $i$ corresponds to the increase of the radius on $10 \mathrm{~m}$.

Search of the optimal value of the transportation distance will be performed in MS Excel using the reduced gradient method. For the technogenic deposit in 2 stages with a height of a stage $12 \mathrm{~m}$ and a loader with a bucket capacity of $7.4 \mathrm{~m}^{3}$, the maximum economically feasible transportation distance, which corresponds to the radius of the radial slicing, will be $183 \mathrm{~m}$.

So, the scheme of development of the technogenic deposit with reinstalling of the open ore chute is given in the fig. 5 .

However, it is obvious that the obtained result of the optimum transport distance should also be verified by the technological criterion, namely: the weighted average performance of the pneumatic wheel loader is to correspond to the performance of the vibrating feeder, as otherwise there will be technological downtime. In our case, the weighted average capacity of the loader is 7686 $\mathrm{m}^{3} / \mathrm{shift}$, and the vibration feeder is $7680 \mathrm{~m}^{3} /$ shift, which corresponds to the condition of equality. Thus, according to fig. 4, for these conditions, the step of reinstalling of the open ore chute $S$ between axes of open ore chutes for the new and old positions will be equal $366 \mathrm{~m}$ as two radii of radial slicing.

\section{Conclusions}

The obtained model allows to minimize the cost for development of the technogenic deposit due to the reasonable timely transfer of the ore chute and productivity increase of the wheel loader. The obtained dependences allow to plan the dynamics of development of the mining front at the technogenic deposit.

Further studies will focus on identifying and optimizing other parameters of the elements of the development system and creating a classification for the development systems of technogenic deposits.

\section{References:}

1. M.E. Kyabbi, Mining waste classification, 2nd edn. (Nedra, Moscow, 2002), pp. 8-17.

2. M. Samir, F. Alama, P. Buysse, T. Nulen, O. Ostanin, E3S Web of Conferences 41, 02012 (2018)

3. Management of mining, quarrying and oreprocessing waste in the European union (BRGM, Orleans, 2001)

4. A.A. Fridman, Economics of exhaustible natural resources (Publishing House of the National Research University Higher School of Economics, Moscow, 2010), pp. 14-32.

5. Yu.G. Vilkul, A.A. Azarian, V.A. Kolosov, Hirnychyy visnyk 96, 3 (2013)

6. V.O. Gneushev, Formuvannya ta rozrobka tekhnohennykh rodovyshch (Volyns'ki oberehy, Rivne, 2013), pp. 7-12.
7. L.P. Rizhova, E.V. Nosova, Gornyy informatsionnoanaliticheskiy byulleten 7, 49-54 (2015)

8. V.D. Evtekhov, Geologo-mineralogicheskiy vestnik 9, 19-26 (2003)

9. U.K. Frolova, Gornyy informatsionno-analiticheskiy byulleten 4, 24-32 (2007)

10. V.V. Kustov, Dissertation, Donetsk National University, 2016

11. O.A. Bubnova, K.V. Babij, K.S. Levchenko, Geotekhnicheskaya Mekhanika 130, 137-143 (2016)

12. Ye.I. Rogov, V.V. Gumenyuk, A. Ye. Rogov, International Journal of Civil Engineering and Technology 9, 1831-1850 (2018)

13. A.G. Temchenko, Resursozberigayuchi tekhnologii girnichogo virobnictva, 2nd edn (Mineral, Krivij Rig, 2000), pp. 102-105

14. K.N. Trubeckoj, A.G. Shapar, Maloothodnye $i$ resursosberegayushchie tekhnologii pri otkrytoj razrabotke mestorozhdenij (Nedra, Moscow, 1993), pp. 65-71

15. V.G. Pshenichnyj, Razrabotka rudnyh mestorozhdenij 92, 39-43 (2008)

16. N. Pyzhik, Y. Hryhoriev, Metallurgical and Mining Industry 3, 298-302 (2015)

17. Caterpillar Performance Handbook (Caterpillar Inc., Peoria, 2016) 